\title{
Mass Customization and Personalization IN SOUTHEAST EUROPE
}

\author{
ANIŠIĆ, Z.; FREUND, R. \& SUZIĆ, N.
}

Abstract: The chapter will present an overview of mass customization (MC) and personalization strategies in the region of Southeast Europe as well as future trends in the area of mass customization and personalization (MCP) as a result of the one decade of active research work of the authors. The economies of the Central and Southeast European countries currently move through very different developmental stages, ranging from the highly industrialized economies of the EU full member states to those transitional and economically unstable systems. Bearing in mind such a complex state of affairs, the introduction of the Mass Customization and Personalization concept has a very special value and represents a unique challenge. The results of mapping showed that there are many MCP activities in the Southeast European region. Starting at Universities as knowledge transfer centres, more and more companies/entrepreneurs realize that MCP models can help to strengthen their competitiveness. Keeping in mind special cultural aspects of the Southeast European region, universities should include MCP business models in their curriculum, build transfer centres for SME and build up stronger networks.

Key words: mass customization, MCP models, Southeast European region development, implementing new strategies
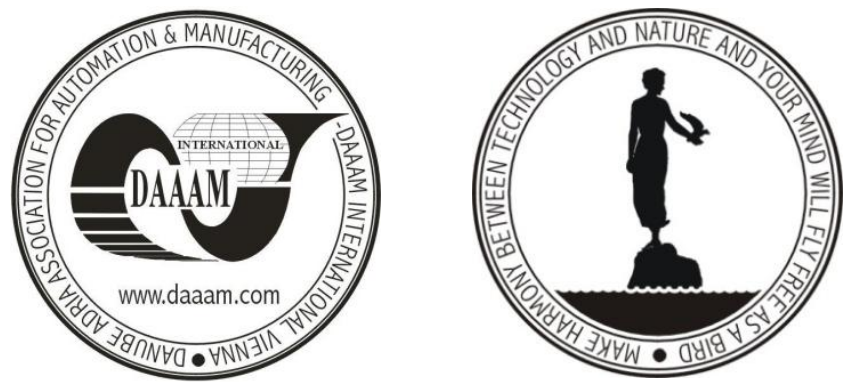

Authors' data: Univ.Prof. Dipl.-Ing. Dr Anisic Z[oran]; Univ.Prof. Dipl.-Ing. Dr Freund R[obert]; Univ.Teach.Assist. Dipl.-Ing. Mr Suzic, N[ikola], University of Novi Sad, Trg Dositeja Obradovica 6, 21000 Novi Sad, Serbia, anisic@uns.ac.rs, nikolasuzic@gmail.com

This Publication has to be referred as: Anisic, Z[oran]; Freund, R[obert] \& Suzic, N[ikola] (2013) Mass Customization and Personalization in Southeast Europe, Chapter 20 in DAAAM International Scientific Book 2013, pp. 389-416, B. Katalinic \& Z. Tekic (Eds.), Published by DAAAM International, ISBN 978-3-901509-94-0, ISSN 1726-9687, Vienna, Austria

DOI: $10.2507 /$ daaam.scibook.2013.20 
Anisic, Z.; Freund, R. \& Suzic, N.: Mass Customization and Personalization in So...

\section{Introduction}

The idea of mass customization is based on the observation that there is a customer interest in products that are adapted to his/her individual needs and preferences, since the adaptation will increase perceived performance. As the standard of living has increased in the last 50 years, individualization has received increased focus, since customization has come within reach of the average consumer. At the same time there has been a massive development of technologies (Svenson \& Jensen, 2001).

The concept of mass customization was first identified in "Future shock" (Toffler, 1971) and was later described in "Future perfect" (Davis, 1987).

Stan Davis, who coined the term in 1987, refers to mass customization when "the same large number of customers can be reached as in mass markets of the industrial economy, and simultaneously they can be treated individually as in the customized markets of pre-industrial economies" (Davis, 1987). In order to address the implementation issues of mass customization, (Tseng and Jiao, 2001) provide a working definition of mass customization which is very useful. The objective of mass customization is "to deliver goods and services that meet individual customers' needs with near mass production efficiency" (Piller, 2003).

In doing so, mass customization is performed on four levels. While the differentiation level of mass customization is based on the additional utility (value) customers gain from a product or service that better corresponds to their needs, the cost level demands that this can be done at total costs that will not lead to such a price increase that the customization process implies a switch of market segments.

The information collected in the course of individualization serves to build up a lasting individual relationship with each customer and, thus, to increase customer loyalty (relationship level). While the first three levels have a customer centric perspective, the fourth level takes an internal view and relates to the fulfilment system of a mass customizing firm: Mass customization operations are performed in a fixed solution space that represents (Piller, 2003) "the pre-existing capability and degrees of freedom built into a given manufacturer's production system" (von Hippel, 2001).

Personalization should therefore be clearly distinguished from customization. Both customization and personalization are based on the assumption that a homogeneous offer is not sufficient in meeting the customers' needs. As defined by the Webster dictionary (2003), personalize means "to make something personal or individual; specifically: to mark as the property of a particular person" (Fung, Boysen, \& Chignell, 2001). The definitions of mass customization and of personalization implies that the goal is to identify customers' needs and then to fulfil these needs with an efficiency that almost equals that of mass production.

It was very interesting to find out what kind of Mass Customization and Personalization is present in the region of Central and Southeast Europe, in which 
economy sectors, how deeply the customers are involved in the process and finally how companies from the region can benefit from implementation of the named strategy. After three successfully organized MCP Conferences (Poland 2004, Poland 2006 and Serbia 2008, 2010, 2012), Mass Customization and Open Innovation (MCOI) Network was established, in 2009, from researchers and institutions that initiated and organized previous conferences. The joint research work through the network started with mapping of MCP subjects in to Google Maps and the obtained results follow.

\section{Implementation of the MCP Strategy in the Region}

The future of mass customization seems to depend highly on the interest of customers in buying customized products. In the last decades the customers forced manufacturers to constantly increase the quality of products and to offer more and more diverse product ranges. In developed societies, like in Western European countries and in the US pressure is put on manufacturers to offer products better matching individual and diverse customers' preferences and expectations. Introduction of mass customization seems to be the best solution for the changes happening on markets" (Babiarz, Freund, Piotrowski, \& Wawrzynkiewicz, 2004; Freund \& Piotrowski, 2005).

\subsection{Results of Mapping Presented in Google Maps}

Identifying present subjects in the field of MCP as a part of the larger research activities was carried out for the following countries of Central and Southeast Europe: Poland, Czech Republic, Slovakia, Austria, Hungary, Croatia, Bosnia \& Herzegovina, Serbia, Montenegro, Romania, Moldova, Albania, FYR of Macedonia, Bulgaria and Hellenic Republic (Greece). Proceedings from MCP Conferences, as well as other dedicated conferences like, IMCM - International Mass Customization Meetings, MCPC - World Congresses, academic or education websites and different company websites are used as reference sources.

All subjects: researchers, institutes, professors, doctors, experts, companies, etc. are divided into four groups of tags:

- Blue: Universities/Researchers (42 items),

- Green: Companies (14 items),

- Red: National websites (1 item),

- Yellow: Conferences (3 items).

Figure 1 presents results of mapping visible in the Google maps at the link given in references. 
Anisic, Z.; Freund, R. \& Suzic, N.: Mass Customization and Personalization in So...

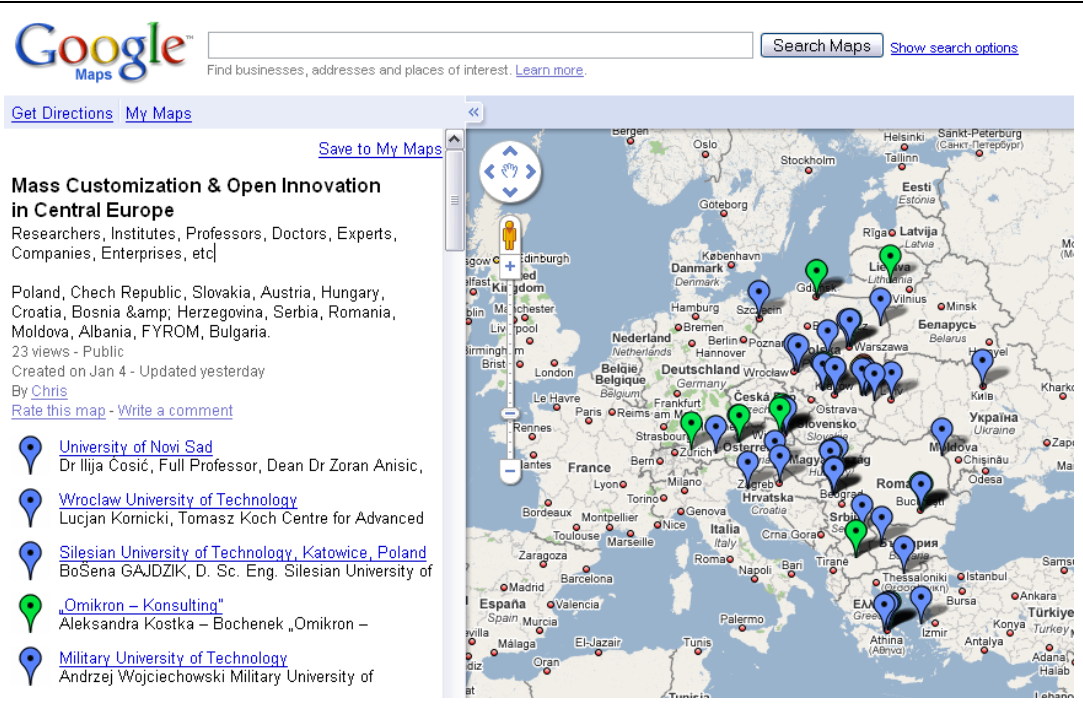

Fig. 1. Mapping of the Mass Customization and Open Innovation activities in

Central Europe (Anisic, Tudjarov, Tsigkas, Chattzopoulos \& Freund, 2009)

\begin{tabular}{|c|c|c|c|c|}
\hline $\begin{array}{l}\text { Mass Customization \& } \\
\text { Open Innovation in } \\
\text { Central Europe }\end{array}$ & $\begin{array}{l}\text { Universities/ } \\
\text { Researchers } \\
\text { Blue colour }\end{array}$ & $\begin{array}{l}\text { Companies } \\
\text { Green colour }\end{array}$ & $\begin{array}{l}\text { Conferences } \\
\text { Yellow colour }\end{array}$ & $\begin{array}{l}\text { National } \\
\text { Websites } \\
\text { Red colour }\end{array}$ \\
\hline Austria & $5 / 17$ & 4 & - & - \\
\hline Albania & - & - & - & - \\
\hline Bosnia \& Herzegovina & - & - & - & - \\
\hline Bulgaria & $1 / 8$ & - & - & - \\
\hline Czech Republic & - & - & - & - \\
\hline Croatia & $1 / 1$ & - & - & - \\
\hline FYROM & $1 / 3$ & 1 & - & - \\
\hline $\begin{array}{l}\text { Hellenic Republic } \\
\text { (Greece) }\end{array}$ & $6 / 10$ & 1 & - & - \\
\hline Hungary & $1 / 1$ & - & - & - \\
\hline Lithuania & - & 1 & - & - \\
\hline Moldova & - & - & - & - \\
\hline Poland & $15 / 30$ & 3 & 2 & 1 \\
\hline Romania & $2 / 2$ & 3 & - & - \\
\hline Serbia & $6 / 17$ & 1 & 1 & - \\
\hline Slovenia & $2 / 4$ & - & - & - \\
\hline Slovakia & - & - & - & - \\
\hline Ukraine & $2 / 3$ & - & - & - \\
\hline Total & $42 / 87$ & 14 & 3 & 1 \\
\hline
\end{tabular}

Tab. 1. Results of mapping MCP activities in Central and Southeast Europe (Anisic et al, 2009)

\subsection{Overview of Configurator Solutions}

Product configurators are important enablers of mass customization strategy (Pine, 1993). Configurators are used as aninterface between the company and its customers.

Configurators can be classified according to business strategy, organization, external or internal use, interaction nature, updating routine, scope of use, their complexity, integration level, solution searching approach and their way of support of 
the products' lifecycle (Blecker, Abdelkafi, Kreuter, \& Friedrich, 2004). But, regardless of the classification parameters of the configurator, it can be used for configuring company products or services (Fuerstner et. al, 2009; Fuerstner \& Anisic, 2009; Fuerstner, et. al, 2012).

In recent years, configuration activities have been intensifying in the SEE region, from the modest beginnings, to today's fairly interesting offer of configurators, in products and services range. Some of the typical configurators will be presented in chapters 2.3. and 2.4.

\subsection{Customization of Products}

As for the products part, customization activities in the region have been noticed in the following industries:

- Computers and computer equipment,

- Cars and car parts,

- Furniture - mostly panel furniture,

- Interior design and

- Apparel (shirts, coats, shoes).

The examples of the configurator tools are given in Figures 2 to 9 representing a sample of the current offer of customized products in the regional market.

One of the most commonconfigurator set is the international brand car configurator (Fig. 2) which is adopted from local dealers to national languages and local markets. Almost all famous brands have this option.

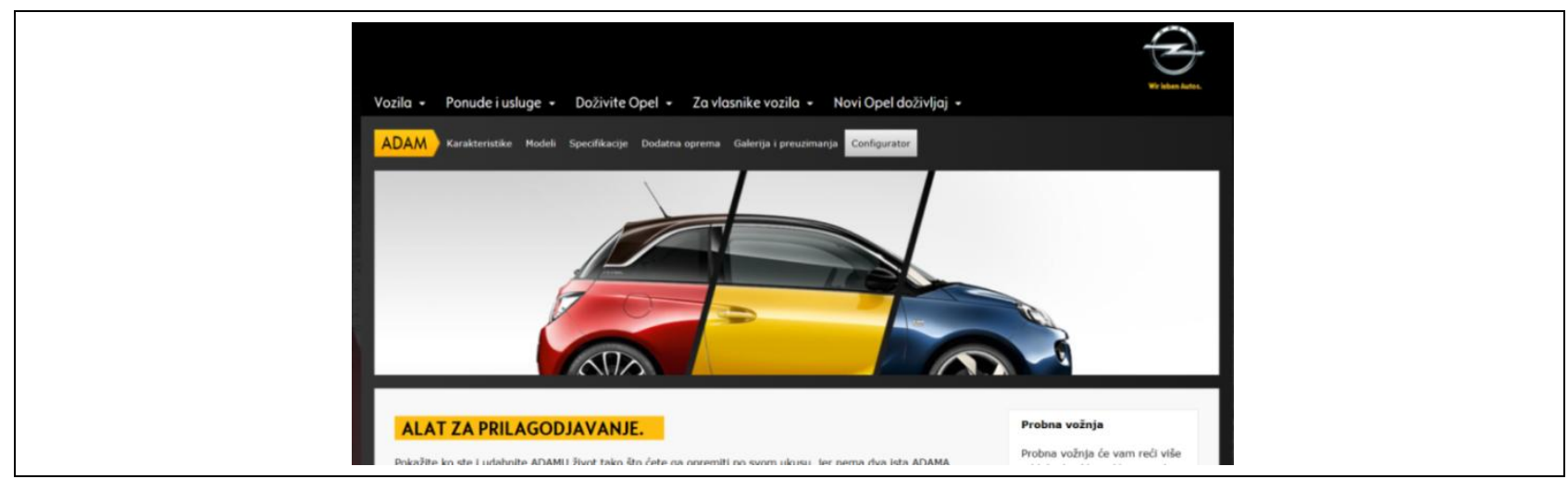

Fig. 2. Configurator for Opel Adam

Configurators for car parts (Fig. 3) are usually the result of large trade companies, located (founded) in the region, which cover a larger regional market, and have translations in a couple of languages. 


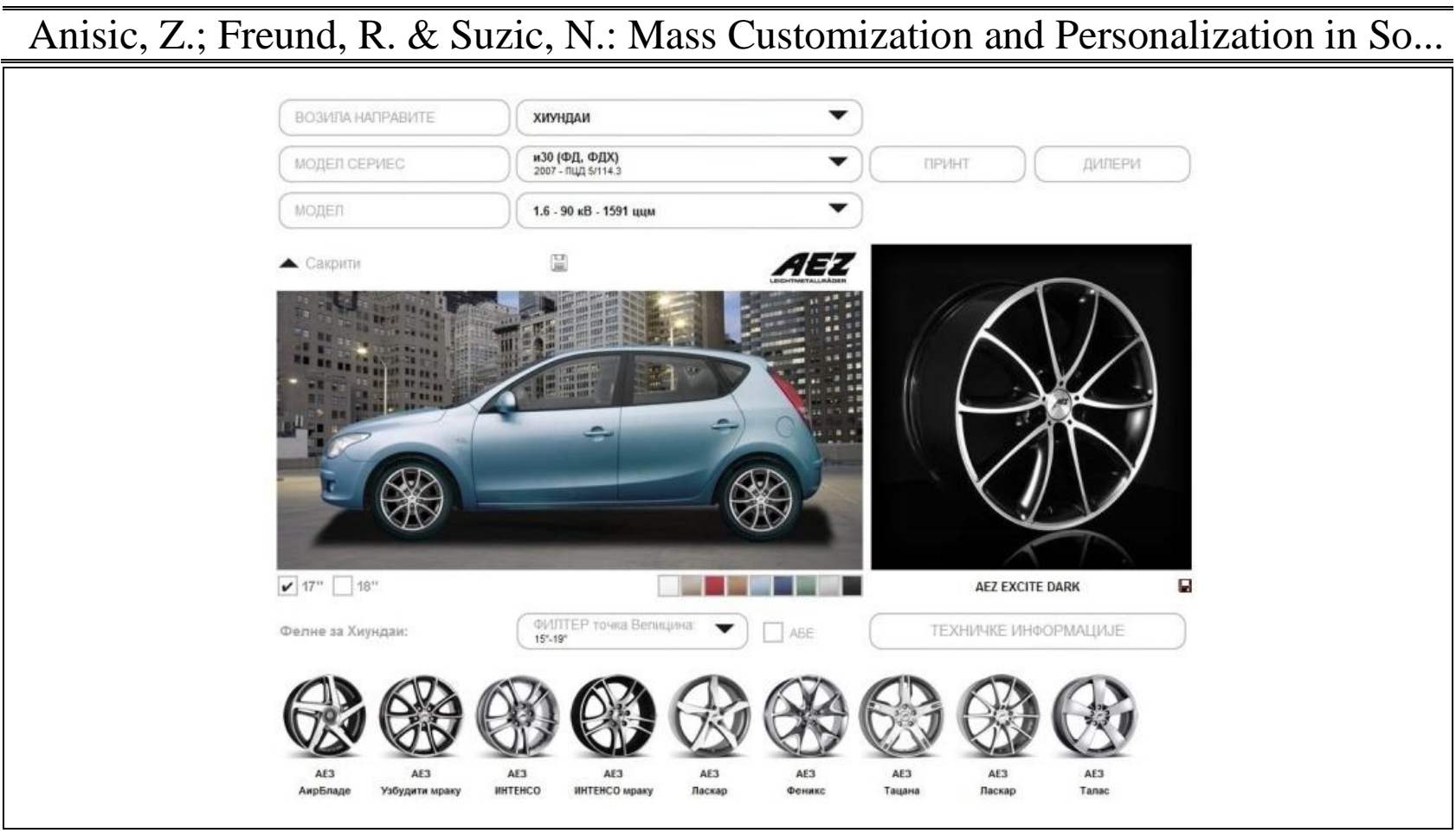

Fig. 3. Car wheels configurator

Computer configurators (Fig.4) are results of local companies, because they are simple technical solutions and could be interesting for smaller markets. Most important companies in this sector have developed their own configurators.

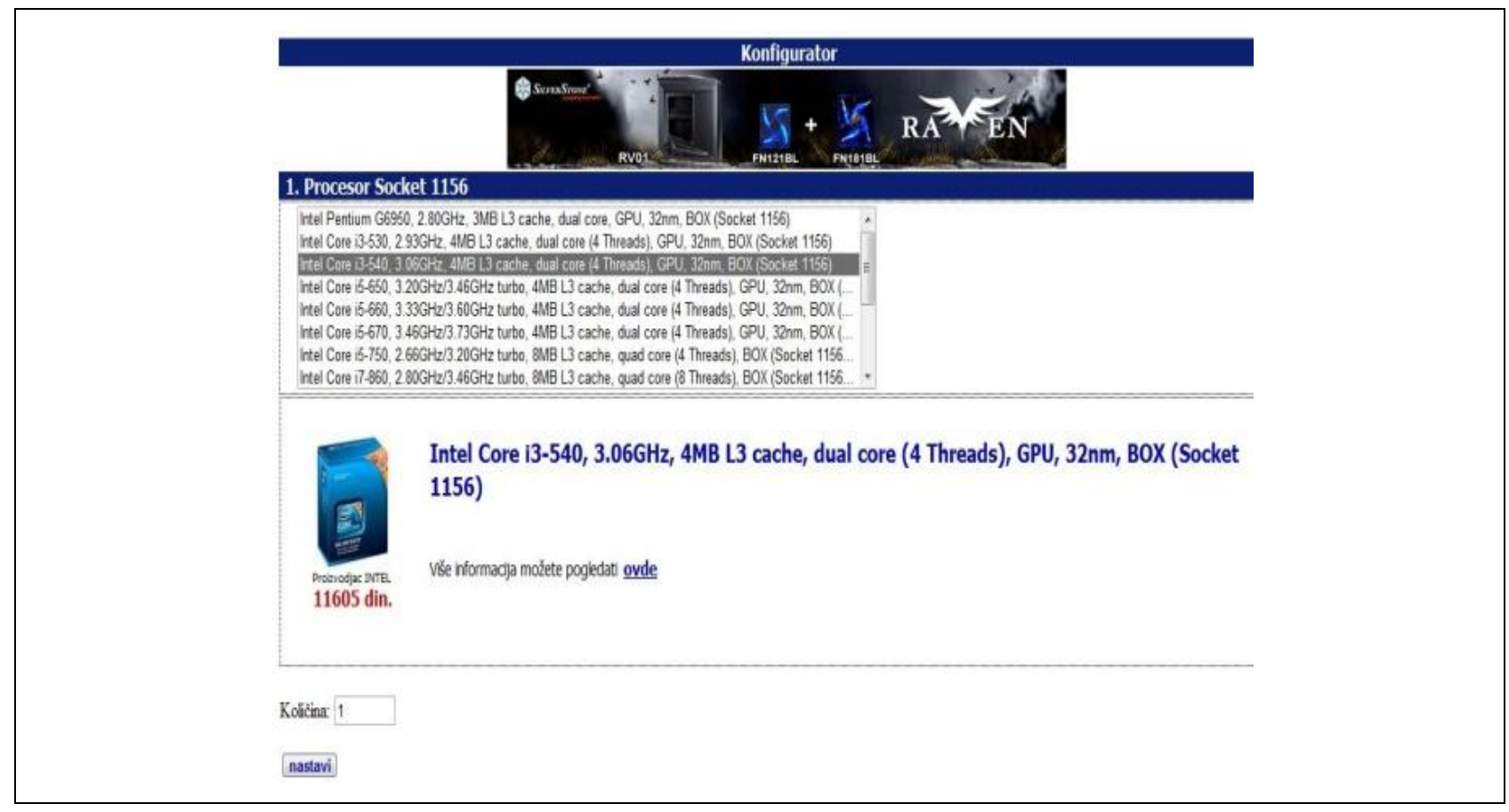

Fig. 4. Computer configurator

The next example is a typical representative of the furniture industry usually dedicated to simple home or office furniture (Fig. 5). Configurators are simple, giving the possibility to change some dimensions, design features and colours. 


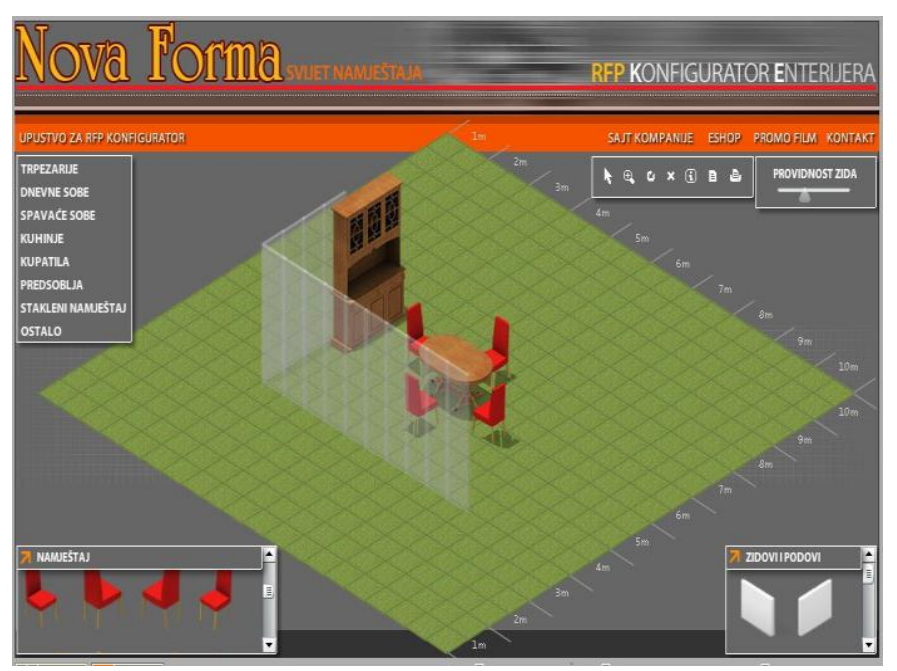

Fig. 5. Furniture configurator

The following figure (Fig. 6) is an example of a strong regional company, covering several countries, which uses configurators mostly for marketing purposes, because configurators are very simple, consist of only 3 steps that could be also presented in a simple table, but in this way the configurator is used only for marketing purposes to attract customers giving them an illusion of a more accurate choice.

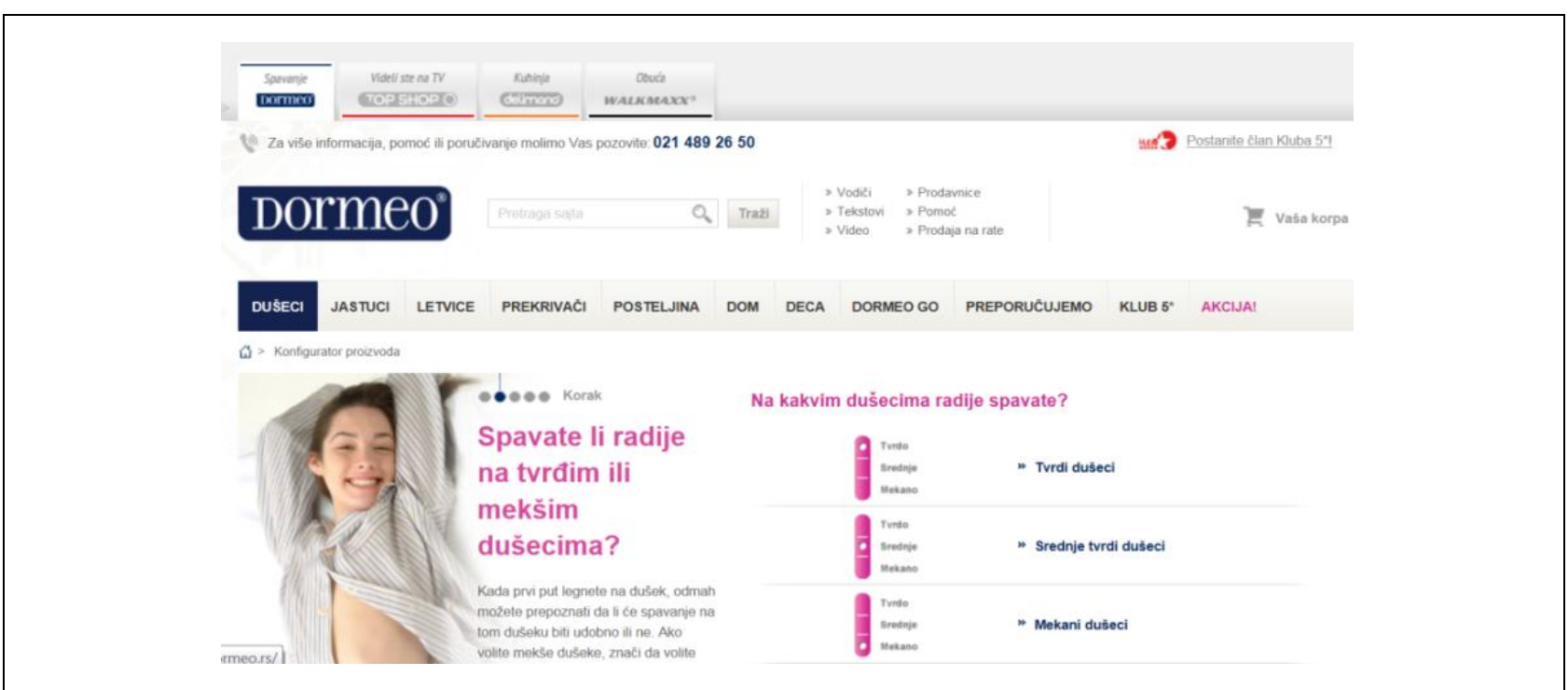

Fig. 6. Mattress configurator

One of the most sophisticated configurators shown in Fig. 7 is used for shirt design. It is developed in 5 languages and covers the regional market. This example is the best business model for regional companies showing how to implement the MC strategy and it will be used to describe it in the next heading. A company is not fully mass customised even if they have a detailed cutting edge configurator. They receive orders through it, giving the opportunity for the customer to design and visualize the product while they manufacture it in the conventional way. Delivery time is only one week, which is quite acceptable. 


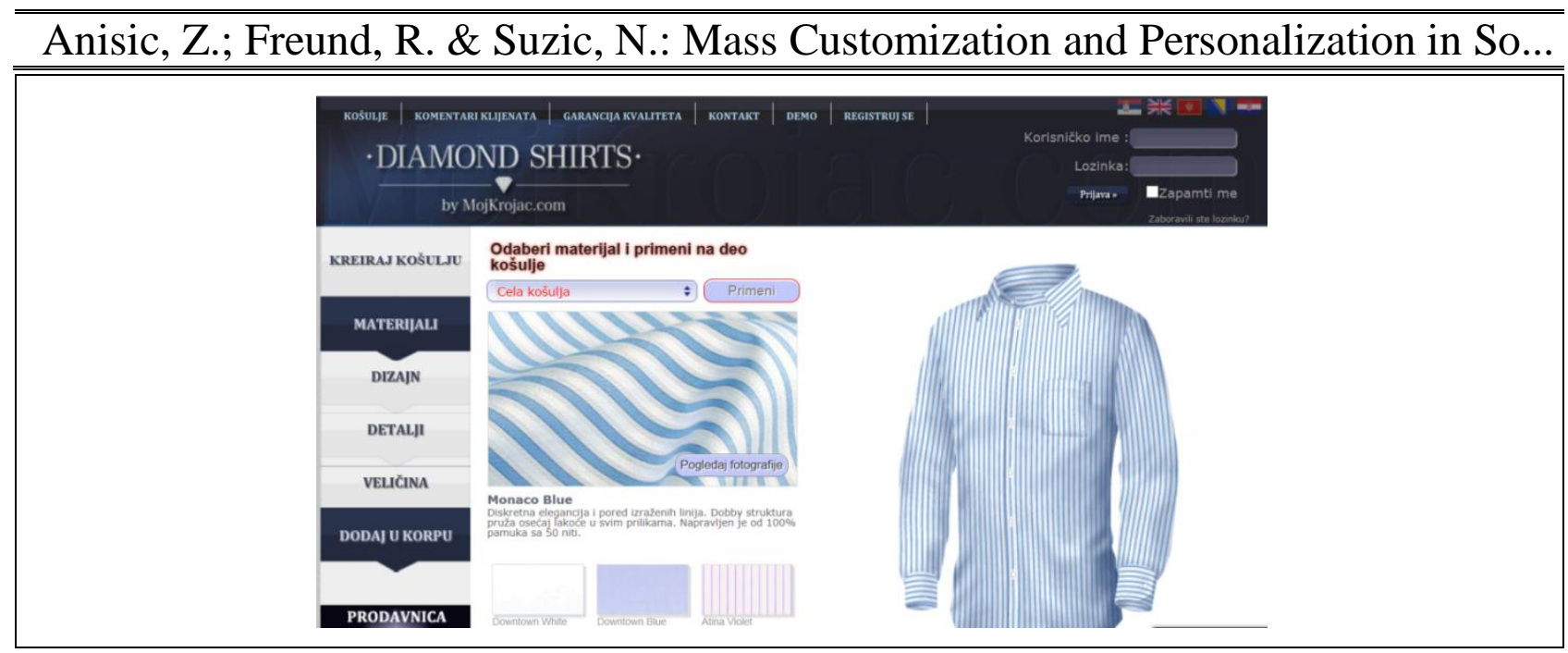

Fig. 7. Shirt configurator

Examples of personalization could be found more frequently. There are also many international, regional, as well as local companies offering the customers to personalize their product and it is becoming more and more popular (Fig. 8).

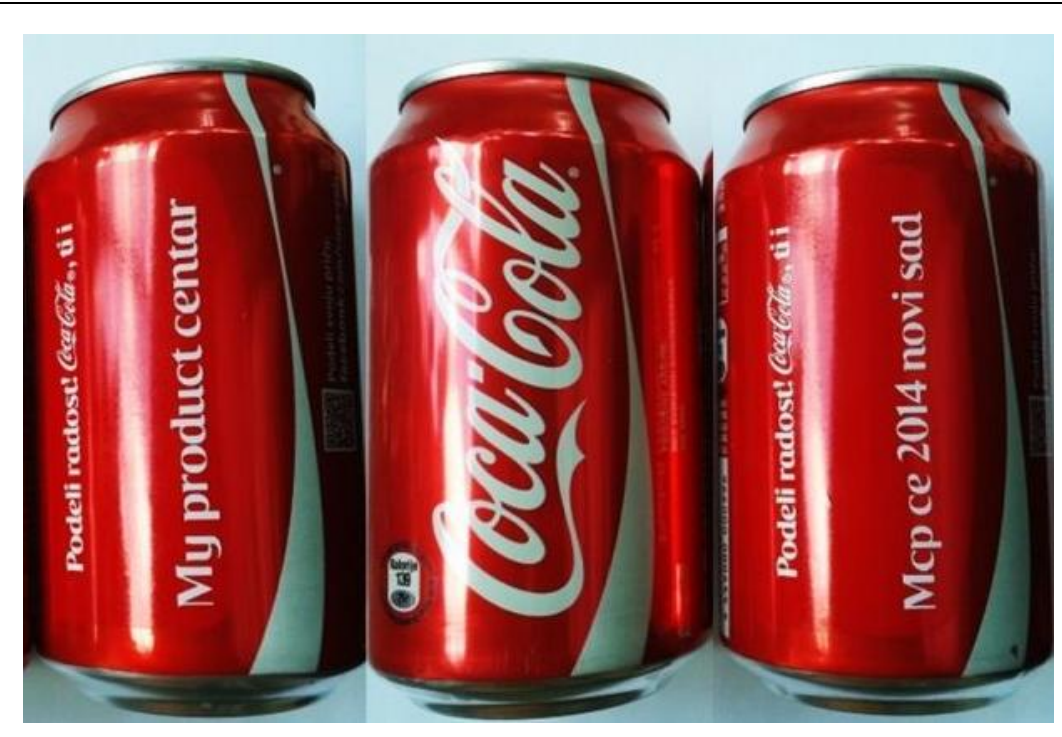

Fig. 8. Personalized can of Coca Cola

\subsection{Customization of Services}

The "decades of the middle class", with a more educated and discerning population, have led to a higher level of expectation from personalized services. In line with this, service providers themselves need to differentiate their offer in some way to sustain market share and profitability. An increasingly common method of service differentiation these days is to introduce options and choices (often associated with premium charges) that give the customer some customization and control over service content and availability. Increasingly, an extremely cost-efficient way of deploying a service to many customers is transforming it into software, that is, automating it and bundling it in some way within the product package. The customer must still be the focus, whether the service is manual or automated; therefore, the product package and the service parts of the package have to treat different customers 
differently. We are not putting service automation in question; rather, we are stressing that any new or enhanced service must be at least as customized as the previous one - manual or semi-manual - to make sense in the context of Mass Customization, for both simple and complex services.

Customization of services, according to the conducted research follows the situation in Western Europe or North America. Possibilities of customization were expanded from typical e-commerce applications into the following areas:

- Transportation services (tickets),

- Financial services (insurance, leasing, etc.),

- Tourism (accommodation, restaurants, etc.)

- Other ( event management, education, etc.).

Two configurators for services can be seen in Fig. 9 and 10.

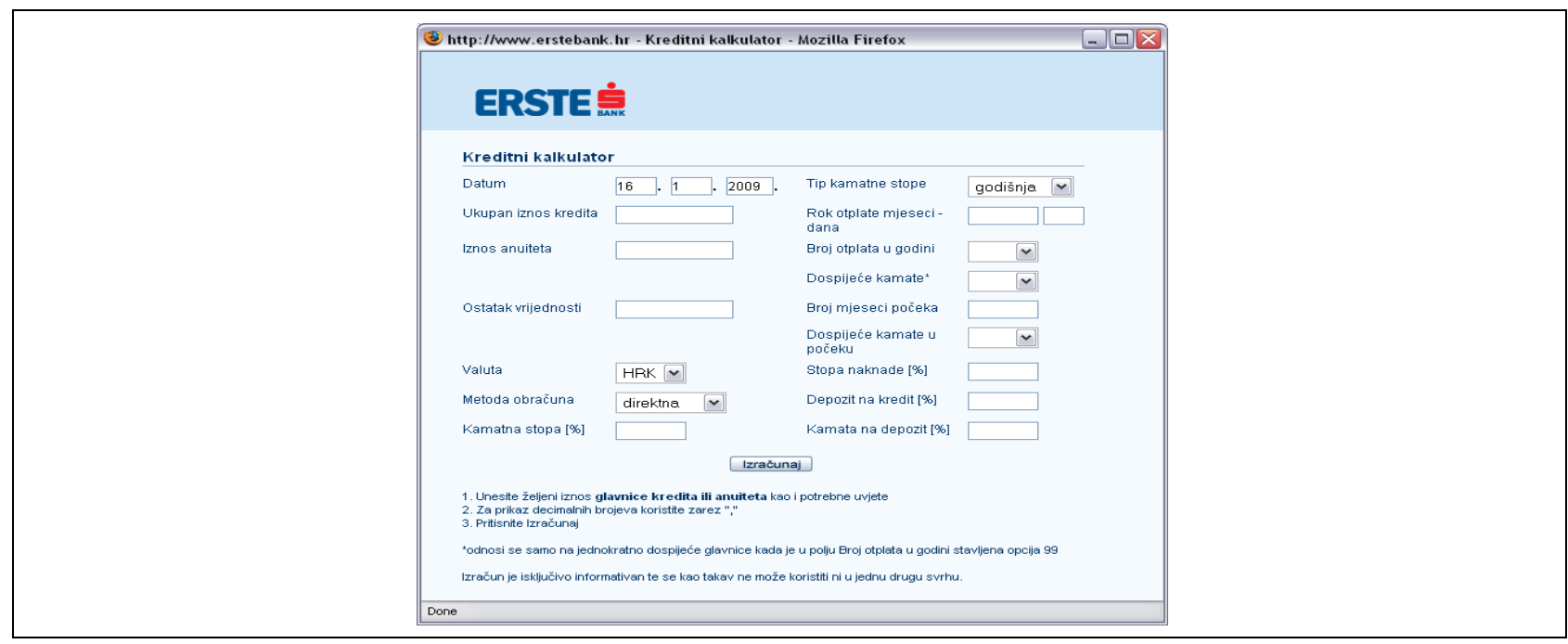

Fig. 9. Configurator of banking services

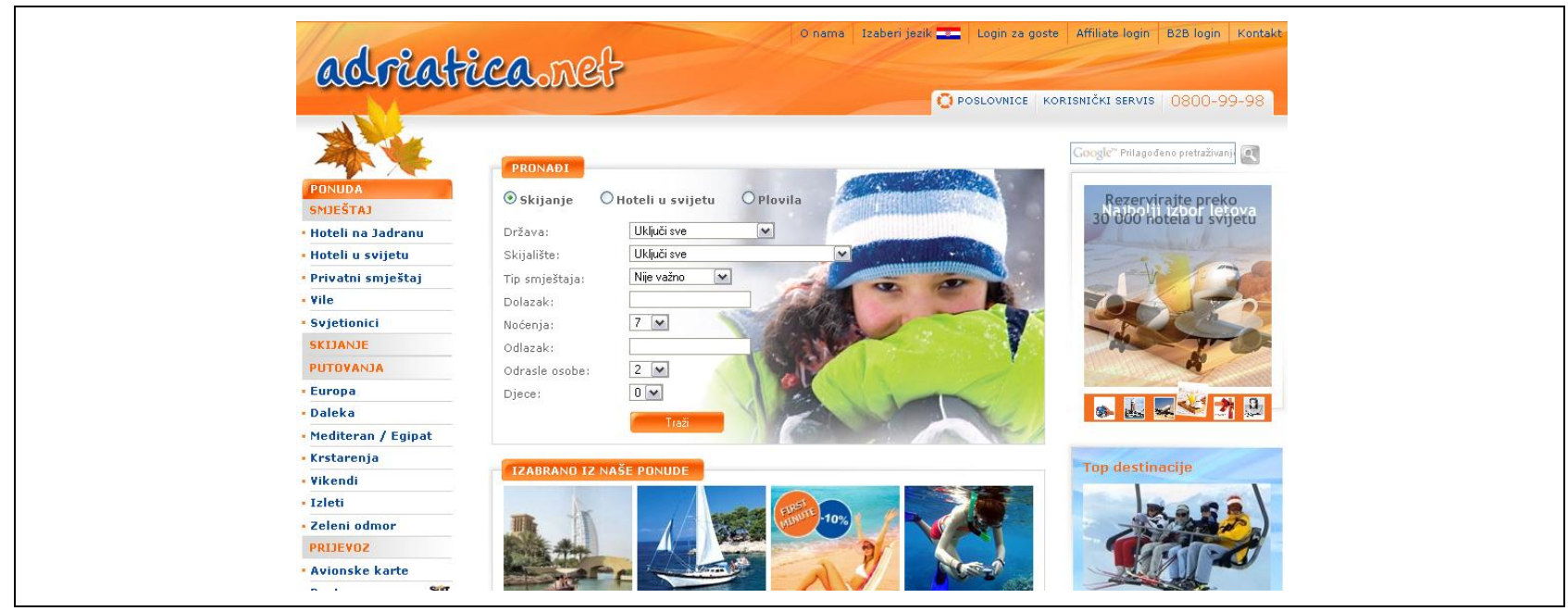

Fig. 10. Configurator of tourist services 
Anisic, Z.; Freund, R. \& Suzic, N.: Mass Customization and Personalization in So...

Customization of services has high potential for implementing the MCP concept (quicker and easier building of business models) instead of product customization , due to the technological level, strength of companies and economies of respective countries. On the other hand, there are many possibilities of developing services, especially in tourism, culture or education in order to integrate, present and promote values of specific regions to the world market through the global net.

\subsection{Concluding Remarks on Implementation of the MCP Strategy in the Region}

The economies of the Central and Southeast European countries are currently going through very different developmental stages, ranging from the highly industrialized economies of the EU full member states to those transitional and economically unstable systems.

Bearing in mind such a complex state of affairs, the introduction of the Mass Customization and Personalization concept has a very special value and represents a unique challenge.

The results of mapping showed that there are many mass customization activities in the region of Southeast Europe. Starting at Universities as knowledge transfer centres, more and more companies/entrepreneurs realize that mass customization business model can help to strengthen their competitiveness. They are usually using only some elements of full MC strategy (to visualize the product) trying to cover several countries in the region giving them advantage over the competition. Keeping in mind special cultural aspects of the Southeast European region, universities should include the mass customization business model in their curriculum, build transfer centres for SMEs and build up stronger networks.

\section{Perspectives on Implementation of the MCP Strategy in Southeast Europe}

Globalization is taking its place in Southeast Europe, like in any other region of the world. That means that the presence of multinational companies in the region is getting stronger. Multinational companies are accustomed to world market trends and aware of the MCP strategy, which is why they implement their strategies in the region accordingly. This means that big companies come to the region bringing previously used MCP solutions thus ostracising universities and institutes from cooperation on the MCP implementation. This situation leads to the conclusion that SMEs are the future of the MCP in the region from the research institutions' point of view. Accordingly, universities and other research institutions should focus on regional SMEs developing their own customized production programs and their own production strategies.

\subsection{Implementation of the MCP Strategy and SMEs}

In order to analyze SMEs from the angle of mass customization we must determine the scope of these companies and what we mean when we say small or medium enterprises.

There are different approaches to defining what small and medium enterprises are. Almost every country in Europe has its own definition. However, there are 
European Commission recommendations for determining company size. According to these recommendations (European Commission, 1996) there is also a subcategory of small companies called micro enterprises consisting of 10 or less employees Table 2.

Enterprises qualify as micro, small and medium-sized enterprises (SMEs) if they fulfil the criteria laid down in the Recommendation which are summarized in the table below. In addition to the staff headcount ceiling, an enterprise qualifies as a SME if it meets either the turnover ceiling or the balance sheet ceiling, but not necessarily both.

\begin{tabular}{|c|c|c|c|c|}
\hline $\begin{array}{l}\text { Enterprise } \\
\text { category }\end{array}$ & Headcount & Turnover & or & Balance sheet total \\
\hline medium-sized & $<250$ & $\leq € 50$ million & & $\leq € 43$ million \\
\hline small & $<50$ & $\leq € 10$ million & & $\leq € 10$ million \\
\hline micro & $<10$ & $\leq € 2$ million & & $\leq € 2$ million \\
\hline
\end{tabular}

Tab. 2. Classification of micro, small and medium enterprises as given in of EU Commission Recommendations (1996)

However, this are not the only criteria relevant to company classification (Vrgovic et. al, 2010), let alone one being enough to show us the road which we are to follow in order to embrace mass customization strategy in our company. The branch of the industry, the type of products manufactured, the characteristics and qualifications of the work force, material flows, the level of automation in the company, the level of information systems integration, using of push or pull principle in production, etc. are all factors relevant to "moving towards mass customization" approach. The implications of these factors will be discussed further in the chapter.

\subsection{Mass customization versus craft customization}

Mass customization is bringing together effectiveness of mass production and individualization of craft production into one paradigm - Fig. 11.

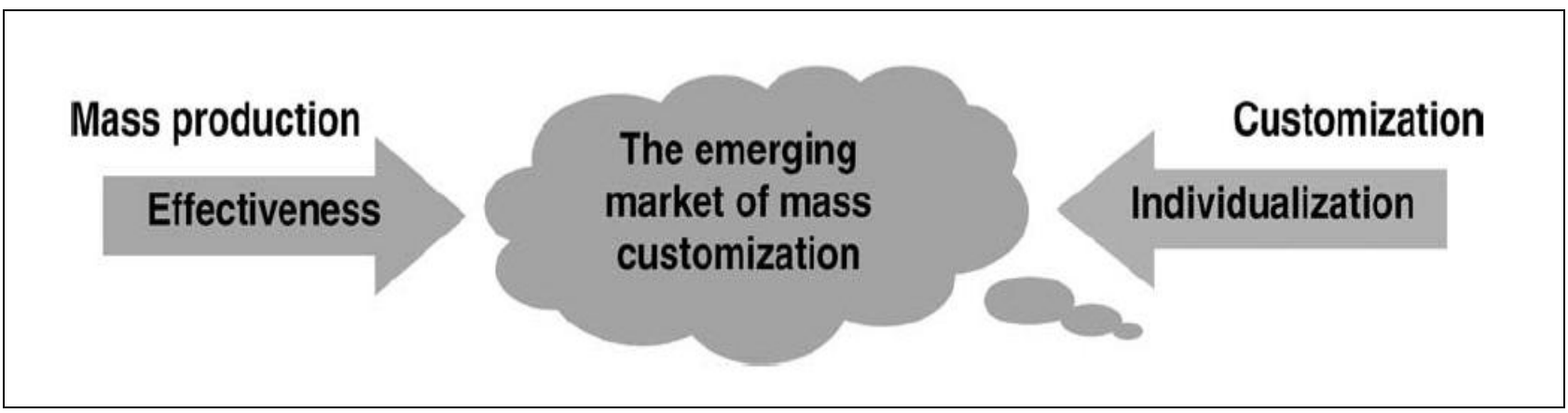

Fig. 11. The development of emerging market of mass customization (Svensson \& Barfod, 2002)

Evolution of production companies since the beginning of production can be summarized in only a few resulting paradigms in the whole of human history (Koren, 2010): 
Anisic, Z.; Freund, R. \& Suzic, N.: Mass Customization and Personalization in So...

- Craft production -peak in late $19^{\text {th }}$ century

- Mass production - peak in the mid 20 $0^{\text {th }}$ century (around 1955)

- Mass customization - active paradigm from the 80s

- Global production - with Personalization and Regionalized production as sub categories

We can also argue that personalized production is nothing more than further development of mass customization and going all the way with fulfilling customer desires and needs, offering evermore intensive customer involvement in the design process.

The development of paradigms would not be possible without the development of manufacturing and technology systems capable of producing the demanded products. In that sense we can say that there are dedicated manufacturing lines, flexible manufacturing systems, reconfigurable manufacturing systems and general purpose machine tools. Every one of these manufacturing systems can be found adequate for one manufacturing paradigm or the other, more suitable for one then the other (Anisic \& Krsmanovic, 2008).

However, in the terms of customization we can distinguish craft customization from mass customization, although the difference may not be always so evident at first glance.

The only difference between craft production and craft customization is the awareness of the craft customizer in meeting the customer needs and often in the existence of a configurator tool in one of the possible forms. The level of technology systems is the same as in craft production - general purpose machine tools. Also, company dealing with customizing is in most cases the company eager to become a mass customizer and implement the economy of scale increasing its production output.

\subsection{Becoming a Mass Customizer}

The development of mass customization markets has its roots in the beginning of mass production in the first half of the 20th century. The development of this paradigm has taken the markets from craft production, trough mass production all the way to mass customization and globalized production of the future markets (Koren, 2010).

Today there are two ways for a mass customization company to emerge - Figure 12. The first is to come from the ranks of mass producers implementing mass customization paradigm, and the other is coming from the ranks of craft producers or craft customizers. 


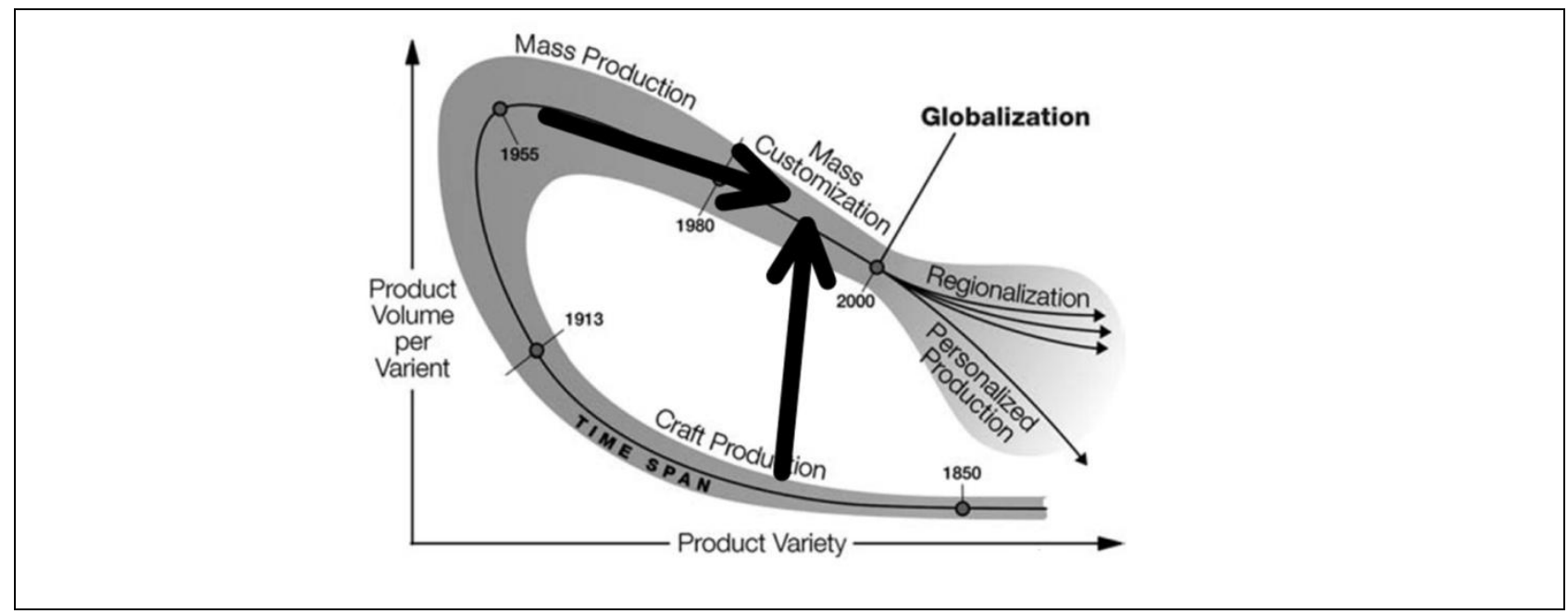

Fig. 12. Development of production systems trough time (Koren, 2010) and ways for mass customizer to emerge

Mass producer will not expect the same results as the craft producer or craft cutomizer when implementing mass customization strategy. Their starting points and expectations will be commpletely different.

\subsection{Analysis of the Regional Markets: the Case of Furniture Market of the Vojvodina Province (Serbia)}

Customized production is acknowledged for competitive advantage in developed countries of the western world. This is the case with the furniture industry of the western countries whose existence is threatened by the countries with cheap labour, mostly companies from China. "While standardised, mass-produced furniture is made more cheaply at similar or better quality in low-cost offshore factories, customized furniture gives manufacturers who are close to customers a sustainable competitive advantage" (Koren, 2010).

In this section we will present a research of the furniture market in Vojvodina, Serbia (Suzić et. al, 2011). The main goal was to establish if there is a market for customized furniture and what kind of customization would be welcomed from the customers point of view. For the purposes of research a questionnaire was composed. The results are derived from that questionnaire and presented in tables and diagrams.

The main questions asked in the research were: Is there a market for customized products in developing countries? And if there is, do manufactures have the ability to produce wide enough a range of products to satisfy the needs of their customers? Are their production structures flexible enough to handle rapid and frequent change of market needs for many variants of products? And lastly, what are the characteristics, the properties of products whose customization will yield most promising results?.

In the light of previously stated facts, a research of furniture market in the province of Vojvodina (Serbia) was conducted during the year of 2010, and the results are presented below.

Sample stratification The research presented in the paper is a part of and introduction to a wider research in the field of production systems in mass customization. The goal of the research was to reveal the furniture market potential in 
Anisic, Z.; Freund, R. \& Suzic, N.: Mass Customization and Personalization in So... the province of Vojvodina (Serbia), and if the potential exists, to determine what features of furniture would be preferable for customization from the customers' point of view in this region.

Five towns in the province were chosen as the research sample: Novi Sad, Sombor, Zrenjanin, Sremska Mitrovica and Bečej. A smaller number of research participants in were from Belgrade, although the city is not a part of Vojvodina, but it is resting on its southern border. Allocation of participants (in percents) can be seen in Tab. 3. The towns in which the research was done can be seen on the map of Vojvodina (Fig. 13).

\begin{tabular}{|c|c|c|}
\hline Label & Town/City & \multirow{3}{*}{} \\
\hline NS & Novi Sad & \\
\hline So & Sombor & \\
\hline Zr & Zrenjanin & \\
\hline SM & Sremska Mitrovica & \\
\hline Beč & Bečej & \\
\hline Bg & Beograd \\
\hline
\end{tabular}

Tab. 3 Allocation of participants (in percents)

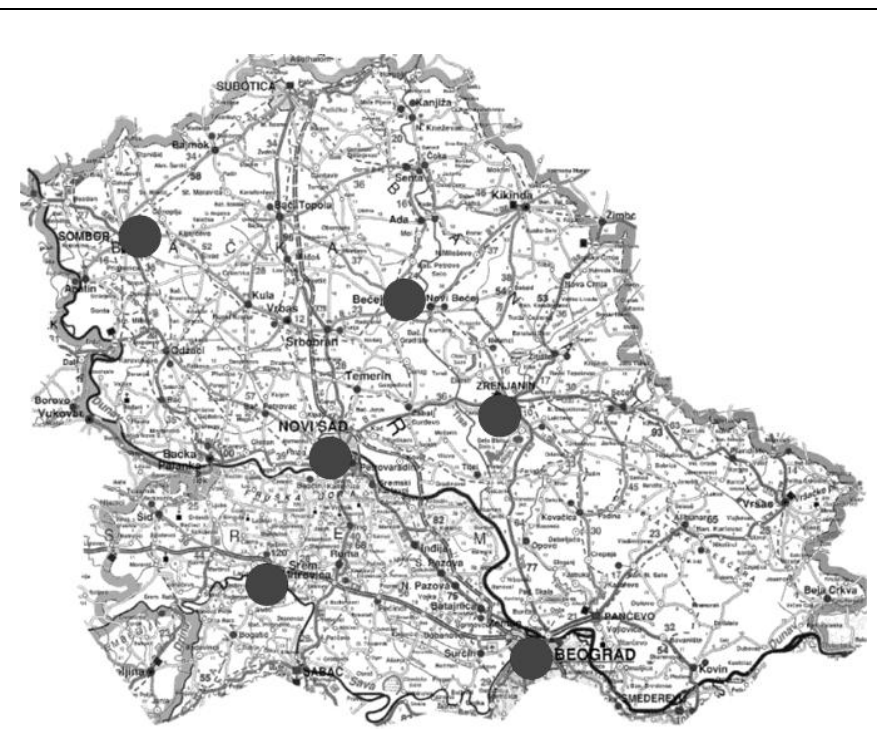

Fig. 13. Towns in Vojvodina (Serbia) in which the research was done (Suzić et. al, 2011)

Although the research included towns and cities, the municipal area was also included (Tab. 4) with $12 \%$ of all participants coming from villages surrounding the towns, and $33 \%$ of examinees coming from suburbs, making up $49 \%$ all together. If we analyze the profile of the surveyed sample, there is a fair balance in terms of gender, age, and generations. (Tab. 4). 


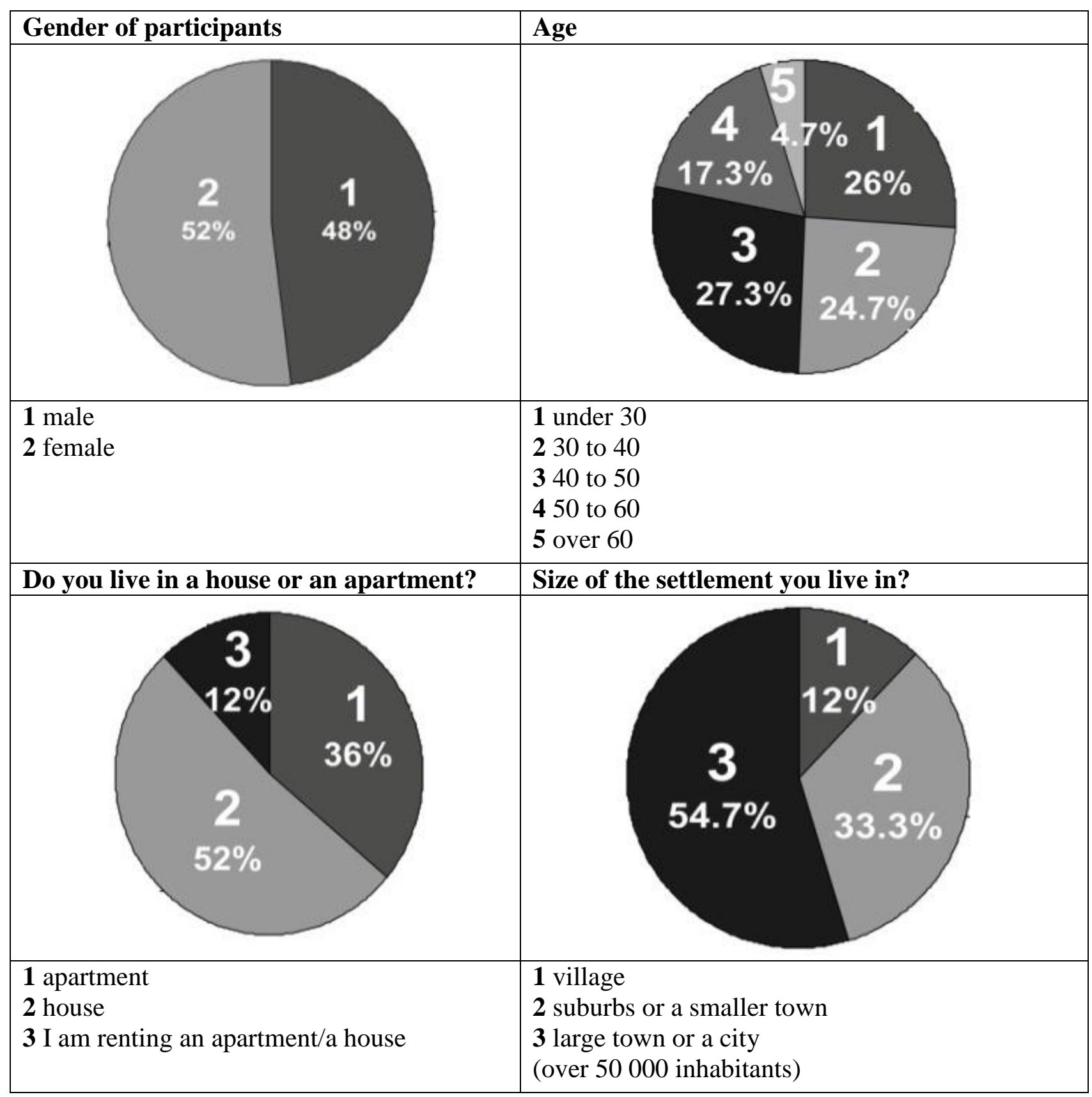

Tab. 4. Profile of participants

Giving the percentages presented in Tab. 3 and 4, we can conclude that the stratification of the sample in the research is good.

\subsubsection{Analyzing buyers' preferences}

For the purposes of the research a questionnaire made of 14 questions was composed. Some of the questions are grouped in tables for better presentation of results. The questions were aimed at finding out the preferences of buyers and prospects of mass customization in the furniture industry in Vojvodina.

The analysis of the collected results has shown that $26 \%$ of examinees do not plan to buy furniture at all in the next two years. The preferences of those who are planning to buy furniture in next two years are given in Tab. 5 . 


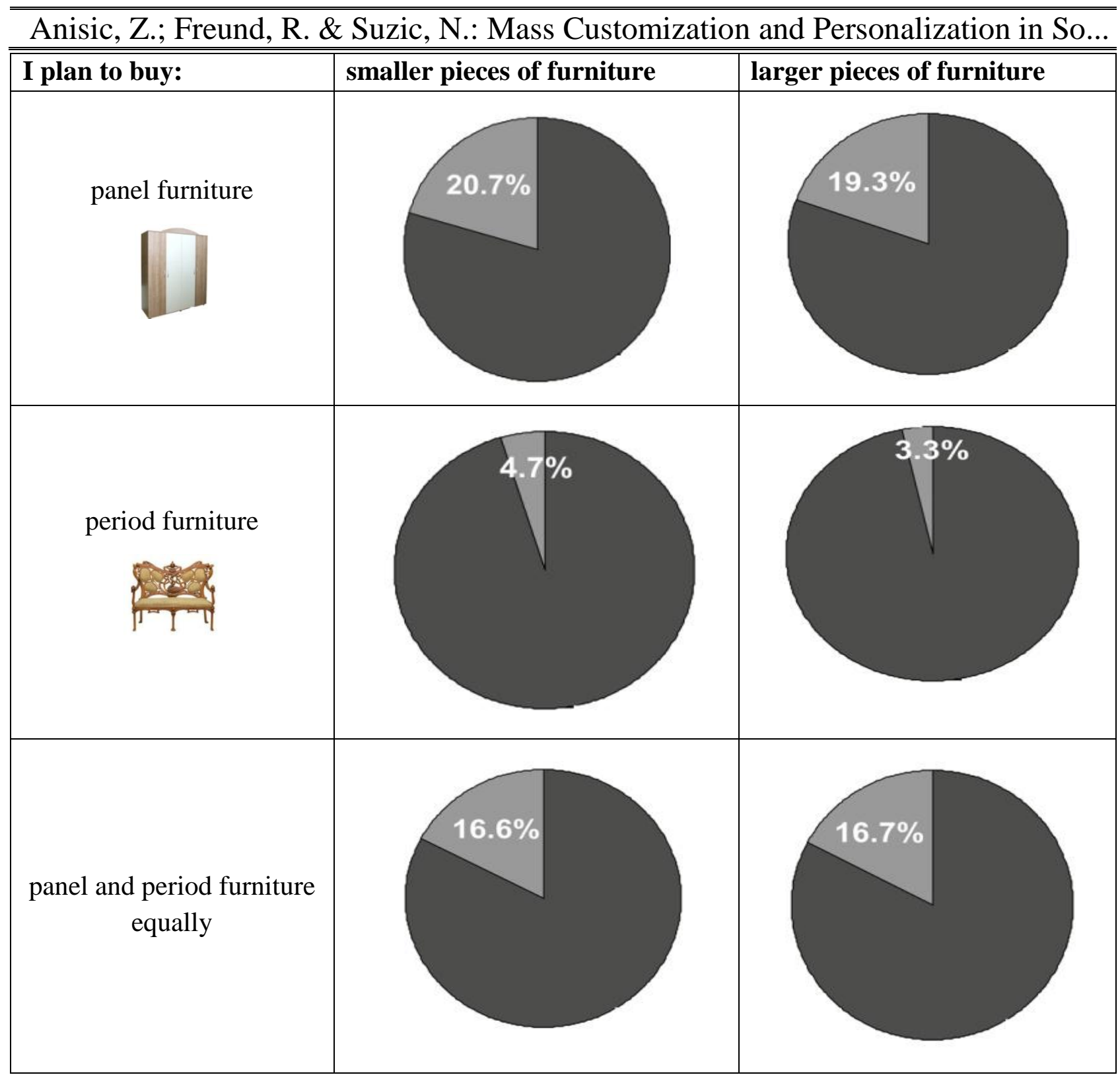

Tab. 5. Preferences of furniture buyers

It must be said that examinees were allowed to choose multiple answers to this question, and that is the reason that sum of percentages in Table 5 exceeds $100 \%$, which did not affect the overall results. Analyzing the results we come to the figure of $40 \%$ of buyers gravitating to panel furniture, $8 \%$ of examinees are buyers of style furniture, and $33.3 \%$ of them would buy both types of furniture. These results show that buyers in Vojvodina are oriented to panel furniture rather than period furniture. The reasons for this can probably be found in the economic situation, not only is Serbia but in the whole SEE region whose countries are still in the transition period. This makes panel furniture a more acceptable and realistic alternative for the buyer. Research results are far from surprising and researchers expected similar findings.

After the preferences of buyers were established, a series of questions was asked regarding the previous experiences of buyers. The emphasis was on the place of purchase, and customers satisfaction with previously bought furniture (Tab. 6). 


\begin{tabular}{|l|l|}
\hline $\begin{array}{c}\text { Where did you most frequently buy the } \\
\text { furniture? }\end{array}$ & $\begin{array}{c}\text { How often does it happen that the offer of } \\
\text { standard furniture does not match your } \\
\text { needs? }\end{array}$ \\
\hline & \\
\hline $\begin{array}{l}\mathbf{1} \text { in furniture stores } \\
\mathbf{3} \text { at carpenters', made to measure } \\
\mathbf{4} \text { nowhere, rarely or other }\end{array}$ & $\begin{array}{l}\mathbf{1} \text { never, standard furniture always or almost } \\
\text { always satisfies my needs } \\
\mathbf{2} \text { sometimes it satisfies my needs, and } \\
\text { sometimes it does not } \\
\mathbf{3} \text { in most cases it does not satisfy my needs }\end{array}$ \\
\hline
\end{tabular}

Tab. 6. Experience with previous purchasing of furniture

Furniture stores have proven as a dominant place for furniture purchase (48.7\%), with a large number of examinees who bought their furniture equally in stores and at carpenters' (36.7\%). Frequent comment that this group of buyers had is that they went to carpenters (and pay higher price) when they did not find what they were searching for in furniture stores.

The customers were then asked if the standard furniture offer satisfied their needs. Only $24.7 \%$ of them answered that standard furniture always or almost always satisfied their needs, $62.7 \%$ said that it sometimes satisfies their needs, and sometimes it did not, and $12.7 \%$ said that in most cases it did not satisfy their needs (Tab. 6).

\begin{tabular}{|l|l|}
\hline \multicolumn{2}{|c|}{ Why standard offer of furniture did not meet your needs? } \\
\hline colour & dimensions \\
\hline $17.3 \%$ & functionality of furniture (number of drawers, \\
\hline & \\
\hline & \\
\hline
\end{tabular}

Tab. 7. Properties of standard furniture offer that customers marked as inadequate 
Anisic, Z.; Freund, R. \& Suzic, N.: Mass Customization and Personalization in So...

Customers who said that standard offer of furniture sometimes satisfied their needs or in most cases did not satisfy their needs where than asked about the furniture properties that did not meet their needs in past (colour, dimensions, quality and functionality of furniture). The examinees could pick out more than one property from given options (Tab. 7). Dimensions (40\%) and functionality of furniture dominate the answers to this question, which leads to the conclusion that there is a need for customization.

After the questions that intendeedd to establish if there is a need for customization in the furniture industry, customers were directly asked if they would like to have the option of customizing their furniture in the next purchase, and eventually how much that would mean to them personally (Tab. 8). A great majority said yes to customization $(93.3 \%), 60 \%$ of them said that it would mean a lot to them.

\begin{tabular}{|l|l|}
\hline $\begin{array}{l}\text { Would you like to have the possibility of furniture customization for your next purchase } \\
\text { (number of shelves, drawers, dimensions, colour, etc.)? }\end{array}$ \\
\hline \begin{tabular}{|l|l|}
3 \\
$60 \%$
\end{tabular} & $\begin{array}{l}6.7 \% \\
33.3 \%\end{array}$ \\
\hline
\end{tabular}

Tab.8. Significance of customization to customers

In many cases customization implies higher prices and maybe even longer delivery time in many cases, and the question is whether the customers are ready for new prices and deadlines. The majority of customers would pay $15 \%$ above the standard price (68.7\%) and wait an additional 15 days for their product (53.3\%). But there was also a part of examinees who were ready to pay a lot more and to wait a lot longer to get the product they wanted (Tab. 9).

\begin{tabular}{|l|l|}
\hline $\begin{array}{l}\text { How much would you be ready to pay } \\
\text { additionally for customized furniture } \\
\text { (number of shelves, drawers, dimensions, } \\
\text { other colour, etc.)? }\end{array}$ & $\begin{array}{l}\text { How longer would you be ready to wait for } \\
\text { customized furniture (number of shelves, } \\
\text { drawers, dimensions, other colour, etc.)? }\end{array}$ \\
\hline $\begin{array}{l}\mathbf{1} \text { up to } 15 \% \text { of the standard price } \\
\mathbf{2} 16 \% \text { to } 30 \% \text { of the standard price }\end{array}$ & $\begin{array}{l}\mathbf{1} \text { I do not want to wait for any reason } \\
\mathbf{3} 31 \% \text { to } 50 \% \text { of the standard price }\end{array}$ \\
$\mathbf{4}$ more than $51 \%$ of the standard price & $\begin{array}{l}\mathbf{3} 15 \text { to } 30 \text { additional days } \\
\mathbf{4} \text { more than } 30 \text { additional days }\end{array}$ \\
\hline
\end{tabular}

Tab. 9. Readiness to pay more and wait longer for customized furniture 
Furthermore the question is what would customers be ready to pay and what would be the range of customization in real life conditions. Even if the question is not so precise, the results are accurate enough to give a complete picture of the furniture market and customers' thinking.

The final part of the questionnaire was intended to clarify what the potential of Internet and computers is, and if they could successfully be used by furniture manufacturers in selling furniture using configurator tools (Tab. 10).

\begin{tabular}{|c|c|}
\hline Do you use the Internet at home? & $\begin{array}{c}\text { Would you be ready to customize and buy } \\
\text { your furniture over the Internet? }\end{array}$ \\
\hline$\underset{63.3 \%}{3}$ & \begin{tabular}{c|c}
2 \\
$29.3 \%$ & 1 \\
& $10.7 \%$
\end{tabular} \\
\hline $\begin{array}{l}1 \text { no } \\
\mathbf{2} \text { occasionally } \\
\mathbf{3} \text { everyday } \\
\end{array}$ & $\begin{array}{l}1 \mathrm{YES} \\
2 \mathrm{NO}\end{array}$ \\
\hline
\end{tabular}

Tab. 10. Using the Internet at home and readiness to customize furniture over the Internet

Data obtained from these two questions (Tab. 10) were encouraging. The Percentage of potential customers using the Internet on daily basis is $63.3 \%$ and the percentage of those who are ready to customize and buy furniture over the Internet is even bigger $(70.7 \%)$. The percentage of occasional users of Internet is also considerable (18.7\%) and gets the sum of Internet users to $80 \%$ altogether.

\subsection{Concluding Remarks on the Prospects of MCP Strategy Implementation in Southeast Europe}

From the analysis of the current state in MCP activities in the region, it seems that SMEs are the future of MCP activity in the region. Multinational companies bring with them their own solutions and strategies and adjust them to local markets if needed, leaving little room for cooperation with research institutions. Therefore, the conclusion is that the future of cooperation in the MCP area for regional institutions lies in the symbiosis with SMEs and enhancing capacities and competitive advantages of local industries.

As for the market readiness for mass customized products, the results of the presented market research brings us to the following conclusions:

- Market of the province of Vojvodina (Serbia) is oriented towards panel furniture. Potential reasons are probably the economic situation in the country and in the whole of SEE region. Bearing this in, mind we can assume that panel furniture will remain a dominant choice of buyers in coming period. 
Anisic, Z.; Freund, R. \& Suzic, N.: Mass Customization and Personalization in So...

- Furniture stores (salons) are the place where most buyers purchase their furniture, and every tenth buyer goes directly to a carpenter.

- A noticable pattern emerged during the research that could almost be considered a rule. The buyer would go to a furniture store in hope of finding a product that would suit their needs, but if they could not find what they were looking for they would go to a craftsman (carpenter) and order exactly what they wanted but for a higher price. So we can say that the potential for mass customization exists, and the fact that the customer came to our store should be used. If our standard offer does not satisfy them, they should be offered customized products which would have lower prices than those of craftsman's.

- Dimensions and functional characteristics of furniture are the main properties which customers were not satisfied with in their past purchases. Mass customization can meet customers' needs in these properties very successfully.

- Majority of buyers $(60 \%)$ would like to have the opportunity to change furniture properties, and $33.3 \%$ would like to have that option even if that would not mean a lot to them.

- As for the readiness to pay more or wait longer for customized furniture, $68.7 \%$ of the examined buyers would pay up to $15 \%$ more than the standard furniture price. The encouraging result is that $22 \%$ of buyers would pay 16 to $30 \%$ more and $9.4 \%$ of them would pay even more. As for a prolonged deadline for customized furniture, $28 \%$ of buyers are ready to wait a lot longer (more than 30 days longer) to have it delivered. So we can concur that there is a population that would agree to higher prices and longer delivery deadlines only to get exactly what they need.

- There are $82 \%$ of Internet users $(63.3 \%$ are everyday users) among the examined buyers, and $70.7 \%$ of buyers would buy furniture over the Internet.

If we sum the complete research results we can say that there is a group of potential buyers of panel furniture (in the province of Vojvodina) which would like to participate in creation of their products and is ready to pay a higher price for it. The only thing left is for the production companies to realise the potential and take this part of the furniture market.

\section{Implementation of Mass Customization - the Methodology}

Mass producers are accustomed to economy of scale. They can produce large quantities of products in a relatively short time. On the other hand, they lack the variety level of a craft producer, craft customizer and mass customizer.. These differences will accordingly result in a different MC strategy implementation process. 


\subsection{Implementation Strategy for Sassproducers}

In establishing mass customized production, mass producers will lean towards a model similar to the one shown in the Fig.14. The model is based on the PUSHPULL principle of production and assumes the use of product configurator as a tool. The model shown is based on work cells (work units) and product platforms and product families as the basis for product design.

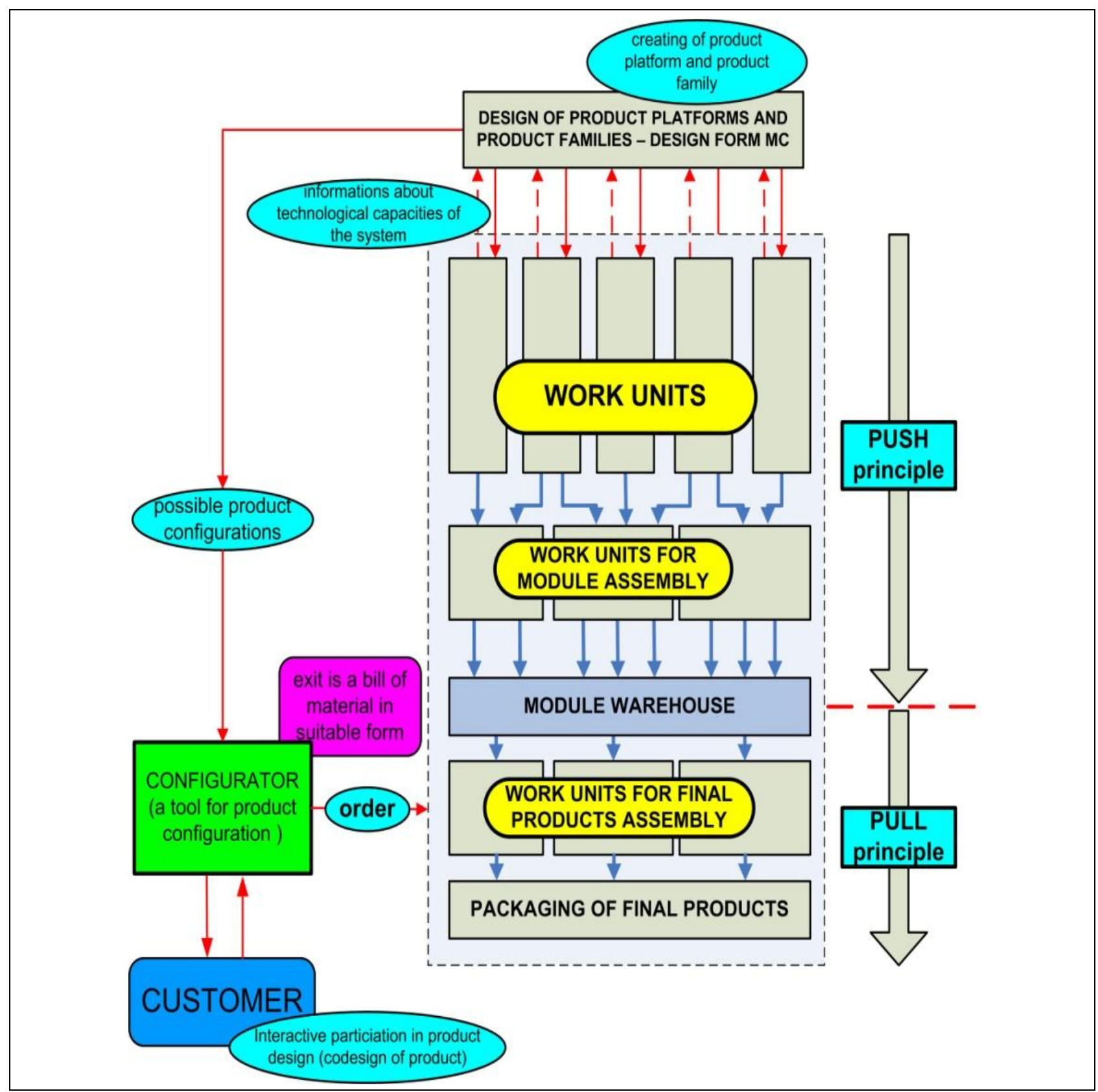

Fig. 14. Model of a production system built on the basis of manufacturing cells oriented towards mass customization market (Suzic et. al, 2012)

According to the model in Fig. 14, implementation of the mass customization strategy into the mass producing system could be presented as in Fig. 15. The steps given would take mass producing company into the mass customizing market. 


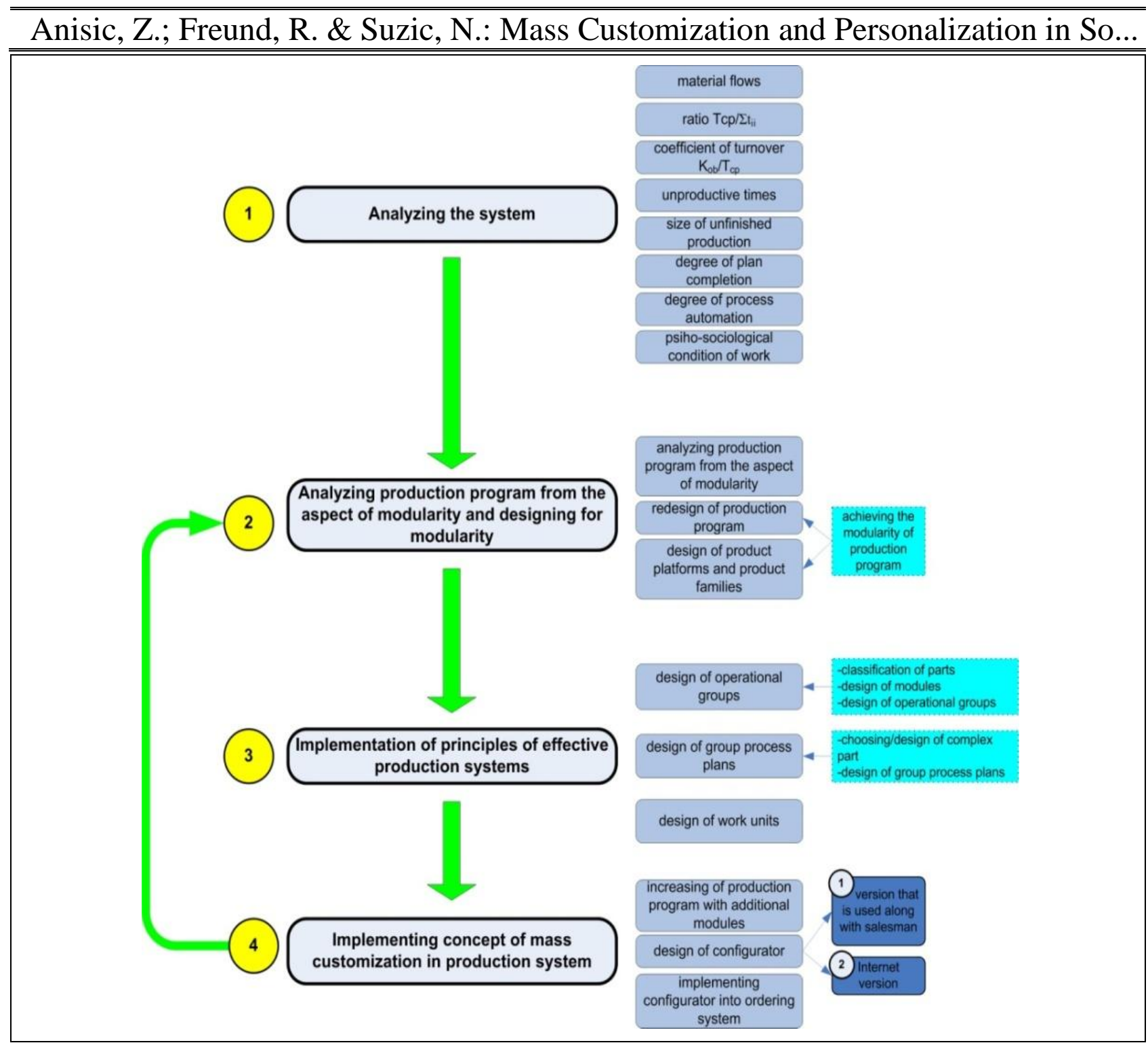

Fig. 15. A model for implementing mass customization into production system (Suzic, 2010)

On the other hand, these steps would not be suitable for a smaller company. Hence the need to develop a methodology for implementation of the MC strategy into SME companies.

\subsection{Implementation Strategy for Craft Customizers}

The question is: Is the mass producer equal to a large company? Is the mass producer always coming from the ranks of large companies or can it be a small or medium enterprise?

The branch of the industry, the type of products manufactured, the traits and qualifications of the work force, material flows, the level of the automation in company, the level of informatics integration, using push or pull principle in production - these are all company characteristics that should be taken into account.

What do SMEs need to do if they want to become mass customizers? Some of the next steps could be taken: 
1. Development of product configurator that can be:

a. sales configurator

b. back-end configurator, which is used with the mediation of an expert

2. Increased automation - in the phases where it is purposeful

3. Dealing with space solution (Figure 16)- defining a production program that can be successfully implemented with the existing manufacturing equipment

4. Increase in production volume - introducing new technologies in manufacturing and organization of production

5. Replacing particular technology systems with CNC systems

6. Introduction of IT systems for successful data management - PDM or PLM (Anisic, Veza, Suzic, Sremcev, \& Orcik, 2013)

7. Developing product platforms and product families

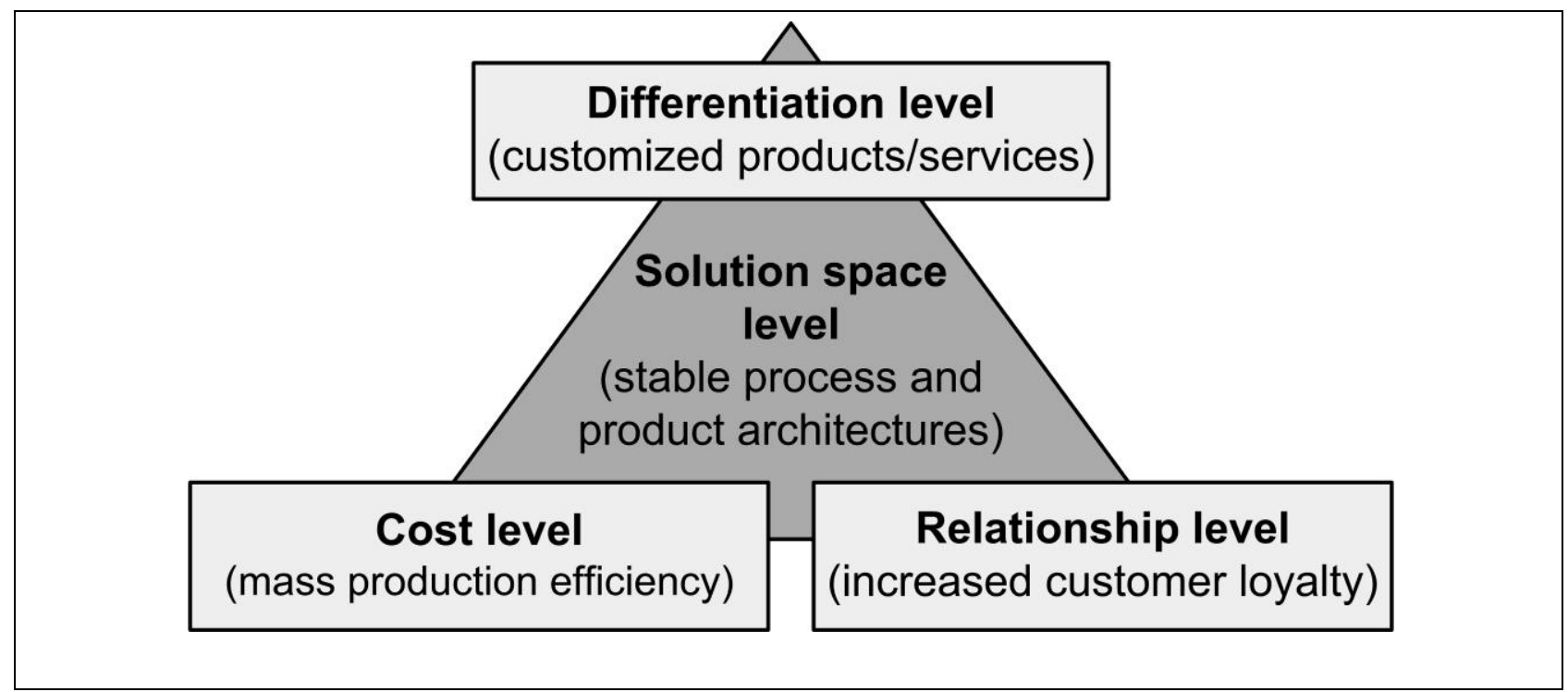

Fig. 16. The four levels of mass customization (Tseng \& Piller, 2003)

Either way the steps should be synchronized with the current position of the company. In that sense the step of precisely defining the starting point of the company becomes crucial.

The size and the lack of power is often seen as a main disadvantage of SMEs who are trying to offer mass customized products to customers.

The company dealing with craft customization can allow itself to have not as well defined solution space since product quantities are smaller than the ones in mass production and can be dealt with in mainly handcraft production. The mass customizer is not in that position. Mass customizers must be careful with solution space since it will affect the production processes if it is not well planned. The mass customizer simply does not have the luxury of misusing solution space. It could prove to be a fatal mistake if made. Therefore the mass customizer must focus their full attention on determining the customer order decoupling point (CODP) - Fig. 17. 
Anisic, Z.; Freund, R. \& Suzic, N.: Mass Customization and Personalization in So...

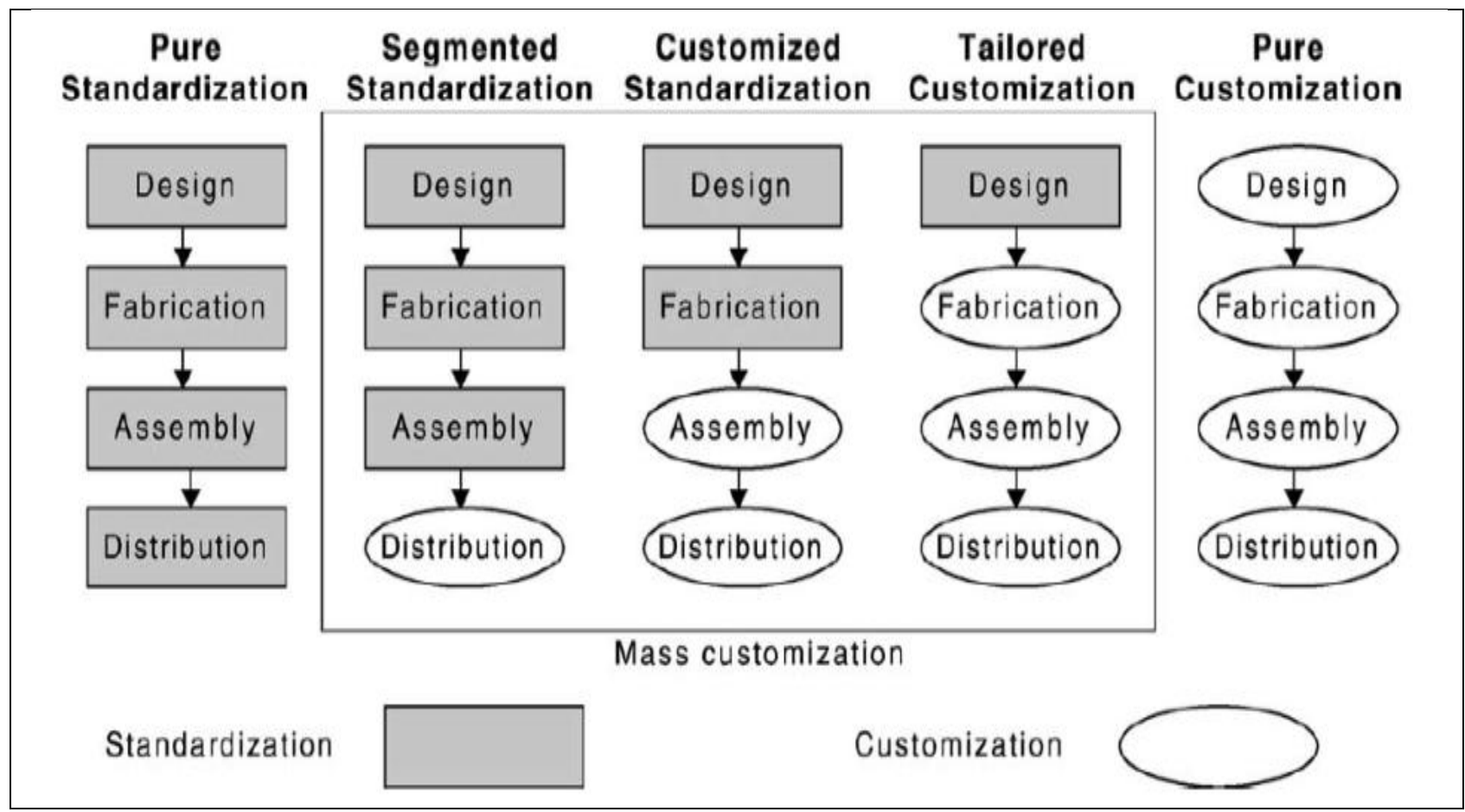

Fig. 17. Division of products into groups based on the point of customization (Lampel \& Mintzberg, 1996)

So what is the SMEs prospect of implementing the MC production?. To answer this question we must be clear on these dilemmas:

- Is the firm size crucial for implementation?

- How does the product portfolio affect the ability to switch to mass customization?

- Is there a potential for implementation of the product platform and product families?

- How hard is it to introduce an information system that will support the configuration of the product?

- Can the production system be easily switched to the PUSH-PULL principle?

- Are PDM systems needed to engage in this type of production?

Questions of this type can continue endlessly. But, at some point the enterprise must be able to answer the ones relevant for their path to implementation.

The truth is that many small companies which started their business in customization failed, but their failure may be the consequence of the market not being ready for customized products of the kind the company offers.

Figure 18 shows the size of the production systems in relevance to the type of the production. All enterprise sizes can undertake at least two types of production. Which of them they choose will depend of the enterprise target market and technological factors relevant to the production. 


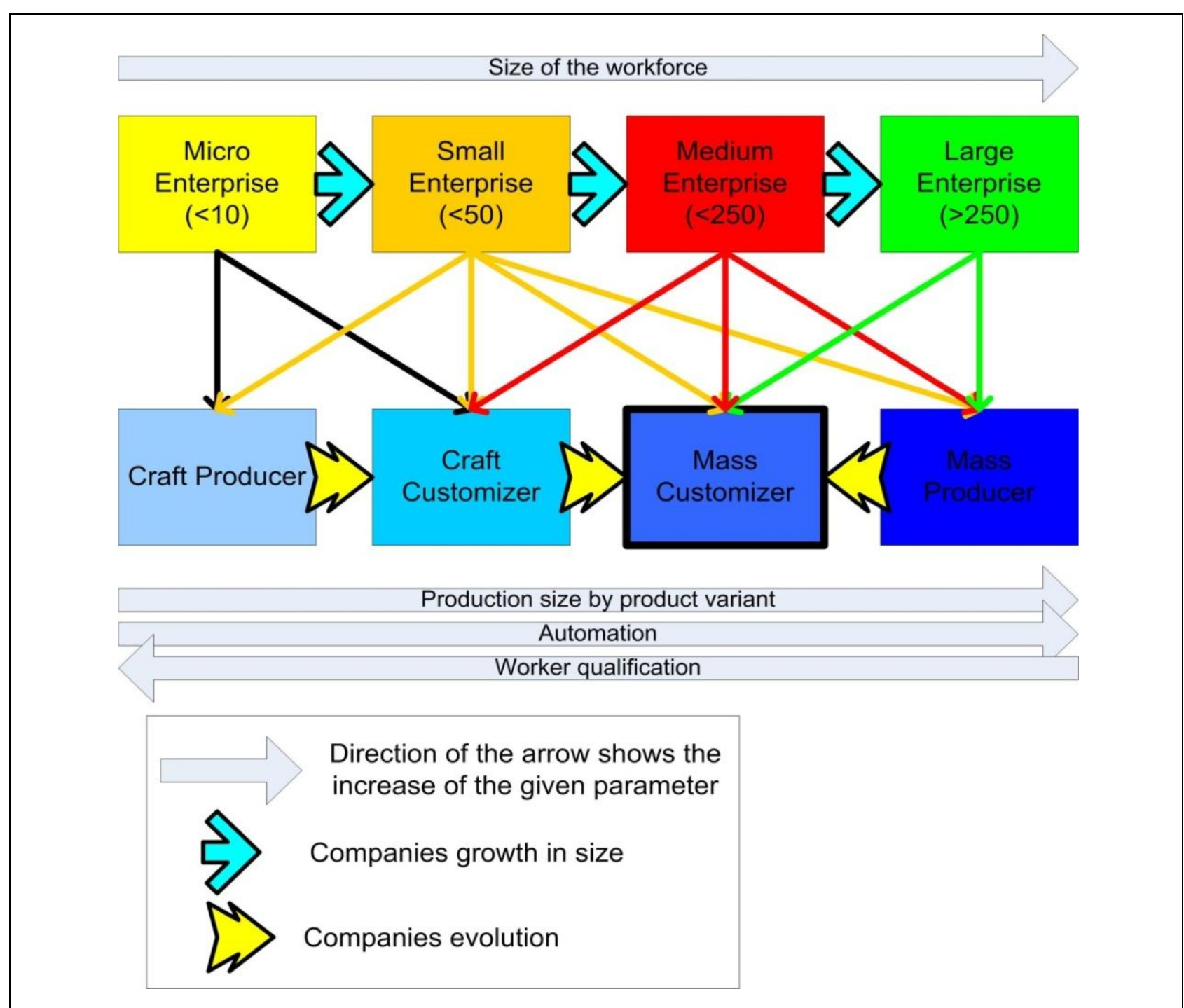

Fig. 18. Enterprise size and production type (Stojanova, Suzic, \& Orcik, 2012)

\subsection{Concluding Remarks on the implementation of Mass Customization}

In conclusion of chapter 4 . we can say that:

- SMEs can fit into the MC paradigm,

- SMEs will use different tools to become a MC manufacturer than large firms,

- SME's and large enterprises do not play at the same competitive advantages in the MC strategy,

- It is possible to identify sets of tools to create a mass customization manufacturer from a SME company,

- It is possible to identify (create) a model strategy for the adoption of MC by SME enterprises,

- Sets of tools SME companies use to achieve the position of MC vary depending on the specific size of company and industries in which the company belongs to. 
Anisic, Z.; Freund, R. \& Suzic, N.: Mass Customization and Personalization in So...

The future research should be based upon:

- Determining all the criteria for classification of SMEs and LE upon the parameters relevant for mass customization production,

- Determining the basic parameters which will give pave the road for implementation of mass customization in SMEs depending on their starting point,

- Conducting empirical studies in this field of research,

- Determining the model for implementation of mass customization strategy in small and medium enterprises.

\section{Chapter Conclusions}

Analyzing the situation in the region of Southeast Europe in terms of implementation of MC strategies, the following conclusions could be summarized. Proper mass customizers, currently present on the market, are international companies that offer product configurators on local languages incorporated in websites of local dealers. In the case of regional companies offering customization there are very few examples due to the lack of efficient manufacturing facilities and relatively low GDP of the population in Southeast Europe in comparison with Western European or Northern American population.

On the other hand, there are lot of companies which partly adopted the MC strategy in the way that they offer customized products through product configurators but the production behind it is more or less craft manufacturing. Delivery time and price is acceptable but most of the profit for those companies comes from batch volume production.

This could be a possible way of implementing MC strategies with maximum chances for success.

Companies also have to work further on possible market niches for suitable products and services that could be customized and adopted by customers.

The servicing industry can also be a very promising field of implementation of MC strategies, especially in tourism industry. Due to the presence of Wi-Fi spots on almost every tourist site and the usage of smart phones by travellers, there is a chance that travellers could be offered much more before or during the trip. There is also potential to further develop configurators to be more automated capturing specific information from the customer profile or even from some social networks. The complexity and time needed to configure some product and service is also a key factor for successful implementation of the MC strategies.

\section{References}

Anisic, Z., Tudjarov B., Tsigkas A., Chattzopoulos C., \& Freund R. (2009). Some Results of Mapping of Mass Customization Activities in SE Europe. Annals of 
Faculty Engineering Hunedoara - International Journal of Engineering, 7 (4), 151156. ISSN 1584-2665

Anisic, Z., \& Krsmanovic, C. (2008). Assembly Initiated Production as a Prerequisite for Mass Customization and Effective Manufacturing. Strojniski vestnik = Journal of Mechanical Engineering, 54 (9), 607-618. ISSN 0039-2480

Anisic, Z., Veza, I., Suzic, N., Sremcev, N., \& Orcik, A. (2013). Improving product design with IPS-DFX methodology incorporated in PLM software. Tehnički vjesnik, 20(1), 183-193

Babiarz, P., Freund, R., Piotrowski, M., \& Wawrzynkiewicz, M. (2004). Prerequisites for successful introduction of Mass Customization strategy in Central Europe, Manufacturing and Management in the 21st Century. Ohrid, Macedonia (1617.09.2008). Available online at: http://robertfreund.de/blog/wpcontent/uploads/2008/12/freund-piotrowski-2004-ohrid.pdf

Blecker, T., Abdelkafi, N., Kreuter, G., \& Friedrich, G. (2004). Product Configuration Systems: State of the Art, Conceptualization and Extensions. Eight Maghrebian Conference on Software Engineering and Artifical Intelligence (pp. 2536)

Davis, S. M. (1987). Future perfect. Reading, MA: Addison-Wesley

European Commission (1996). 96/280/EC: Commission Recommendation of 3 April 1996 concerning the definition of small and medium-sized enterprises. Official Journal L 107 , 30/04/1996 P. 0004 - 0009

Fung, G., Boysen, A., \& Chignell, M. (2001). A Model of Personalization. The 1st World Congress on Mass Customization and Personalization, Hong Kong.

Fuerstner, I., Anisic, Z., \& Cosic, I. (2009). Overview of the Current Research Results of Mass Customization. Advances in Production Engineering \& Management, 4 (1), 47-58. ISSN 1854-6250

Fuerstner, I., \& Anisic, Z. (2009). Intelligent Product Configurator - The New Approach in Thermo Insulation of Buildings. Annals of Faculty Engineering Hunedoara - International Journal of Engineering, 7 (2), 165-170. ISSN 1584-2665. Fuerstner, I., Anisic, Z., \& Takac, M. (2012). Product Configurator Self-Adapting to Different Levels of Customer Knowledge. Acta Polytechnica Hungarica - Journal of Applied Sciences, 9 (4), 129-150. ISSN 1785-8860

Google maps. Mass Customization and Open Innovation in Central Europe. Retrieved from http://maps.google.com $/ \mathrm{maps} / \mathrm{ms}$ ?ie=UTF8\&hl=en\&msa=0\&msid= 115394000225018160781.00045 faaf54d 785f4ec64\&ll=47.872144,23.203125\&spn $=2$ $8.231113,79.101563 \& \mathrm{t}=\mathrm{h} \& \mathrm{z}=4$

Koren, Y. (2010). The global manufacturing revolution: product-process-business integration and reconfigurable systems (Vol. 80). Wiley

Lampel, J., \& Mintzberg, H. (1996). Customizing Customization, Sloan Management Review, 38, 21-31

Pine, J. B. (1993). Mass Customization: The New Frontier in Business Competition. Cambridge, MA: Harvard Business School Press 
Anisic, Z.; Freund, R. \& Suzic, N.: Mass Customization and Personalization in So...

Piller, F. (2003). Mass Customization News. Newsletter on Mass Customization, Personalization and Customer Integration, 6 (1), May 2003

Svensson, C. \& Jensen, T. (2001). The customer at the final frontier of mass customisation. The 1st World Congress on Mass Customization, Hong Kong Svensson, C., \& Barfod, A. (2002). Limits and opportunities in mass customization for "build to order" SMEs. Computers in Industry, 49(1), 77-89

Suzic, N., Vrgovic, P., \& Rikalovic, A. (2011). Potentials of Mass Customization on Furniture Market of Vojvodina. Acta Technica Corviniensis, 4(2), 83-86

Suzic, N., Stevanov, B., Cosic, I., Anisic, Z., \& Sremcev, N. (2012). Customizing Products through Application of Group Technology: A Case Study of Furniture Manufacturing. Strojniški vestnik-Journal of Mechanical Engineering, 58(12), 724731

Suzic, N. (2010). Researching the possibilities of applying concept of mass customization in effective production systems environment (Magister Thesis). University of Novi Sad, Serbia

Stojanova, T., Suzic, N., \& Orcik, A. (2012). Implementation of Mass Customization Tools in Small and Medium Enterprises. International Journal of Industrial Engineering and Management, 3(4), 253-260.

Toffler, A. (1971). Future shock. New York: Bantam Books

Tseng, M. M., \& Jiao, J. (2001). Mass Customization. In: Handbook of Industrial Engineering G. Salvendy (Ed.), 3rd edition (pp. 684-709). New York: Wiley.

Tseng, M. M., \& Piller, F. T. (2003). The Customer Centric Enterprise-Advances in Mass Customization and Personalization. New York/Berlin: Springer

Von Hippel, E. (2001). Perspective: User Toolkits for Innovation. The Journal of Product Innovation Management, 18, 247-257

Vrgovic, P., Glassman, B., Walton, A., Vidicki, P., \& Suzic, N. (2010). Market driven inventions in SMEs - a model for growing economies by connecting entrepreneurial inventors with local companies. Annals of Faculty Engineering Hunedoara - International Journal of Engineering, 8(2), 219-224.

Webster Online (2003): Retrieved from: http://www.webster.com/cgibin/dictionary?book=Dictionary\&va=personalize 